\title{
Questioning practice
}

The RIBA has no reliable figures on the volume of buildings in the UK that are built without architects, but experience tells us that the profession's impact on the built environment as a whole is depressingly limited. Teaching architectural students how to think and build 'sustainably' is, rightly, a growing concern in architectural education, but the graduates' ultimate impact on the wider world will be modest compared with the builders, technicians, surveyors and 'architectural designers' who still dominate the production of much of our building stock.

Paul Hymers, writer of the vastly successful book Home Conversions, describes 'a good designer' as 'one who possesses the necessary skills of draughtsmanship and is familiar not only with the details of construction, but also with the problems and regulations relating to the work.' It sounds like a job description for an architectural technician and at no point is there any mention of the words 'design' or 'quality'. Hymers describes the RIBA as a 'club', immediately endowing the chartered architect with an aura of elitism - and implying a concomitantly inflated fee - in the mind of a potential client. In so doing he reinforces what might be called the new "culture of amateurism', in which the traditional role of the professional is consistently undermined. How many members of the public, one wonders, know the difference between 'architectural services' and the services of architects?

Sadly, Hymers' scepticism about architects is hardly confined to the DIY end of the market. As RIBA President Sunand Prasad points out in his letter (p. 101), government procurement practices appear to be based on the assumption that architects cannot be trusted to use public money well. To promote the cause of better architecture, architects need to encourage a far broader appreciation of what they do. In this respect, Prasad is to be praised for the development of Design Quality Indicators, because here at last is a tangible expression of what architects can actually bring to a project - something depressingly few seem to understand let alone value.

Architects also need to relinquish the belief that they are special, gifted and misunderstood while still recognising that, as a profession, they command unusual and increasingly relevant skills of research, planning and integration. By opening up the profession to greater public scrutiny and to a broader range of potential clients, architects are well placed to become more widely relevant - as enablers, as teachers, as people with real skills in planning, and real knowledge about working with the environment. The Alternate Currents conference in Sheffield that took place in November 2007 , from which several papers in this issue have been drawn (see report and introduction, pp. 105-111), celebrated the activities of many such practitioners, who see their role as making things happen in the wider community: infiltrating, negotiating and acting as an impartial voice for disempowered people - as in the work of 'Supertanker' in Copenhagen (pp. 173-181) - confronted by a voracious development industry.

THE EDITORS

\footnotetext{
Notes

1. Paul Hymers, Home Conversion (London: New Holland, 2003), p. 16. This book is so popular that it is sold at a discounted rate by the highly popular retailer The Book People.

2. C. Leadbeater, 'Amateurs: A 21st Century Remake', RSA Journal, 5507 (June 2003), 22-25.
} 


\section{architectural research quarterly}

\section{Subscribe now for 2009}

Innovative in conception, unique in breadth and generously illustrated, this pace-setting quarterly publication from Cambridge University Press links, on a global scale, the worlds of architectural practice and research. arq regularly includes extensive peer-reviewed sections on design, history, theory, construction, environmental design, information technology and practice - as well as structures, urbanism and documents. These are supplemented by letters, reports, reviews, a directory of specialist research centers and consultancies and an annual index. Each issue opens with a leader and closes with insight, a personal end-piece. In its ten year history, arq has published work from all over the world: from Chile to Sweden and from Japan to the Netherlands - with a strong representation from the United Kingdom and United States. arq, like architecture itself, is all-embracing and written by and for both practitioners and academics. It provides an outlet for all those who wish to disseminate their work to an international audience.
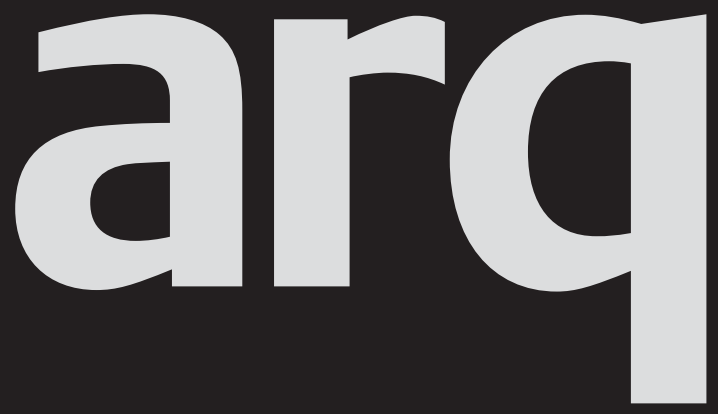

Please enter my subscription to arq: architectural research quarterly, volume 13, 2009 $\square$ E186/\$308 institutions print and electronic $\square E_{30} / \$ 50$ students print only

$\square$ £42/\$64 individuals print only

EU residents only. VAT may be payable at your local rate if not registered.

Our VAT registration number: GB 214141614 If registered, your VAT registration no:

Total subscription payment $£ / \$$ EU residents only, if not registered add VAT at appropriate rate

Canadian residents, add 7\% GST \$

Name

Total $\mathbf{E} / \mathbf{\$}$

Address

Payment enclosed

Cheque in sterling or US dollars

(payable to Cambridge University Press)

Credit Card - VISA | MasterCard | American Express (delete where applicable)

Card no

Expiry date

Signature

Photocopy this page and send your order to:

Journals Customer Services, Cambridge University Press, The Edinburgh Building, Cambridge, CB2 8RU, UK

T $+44(0) 1223326070$

$\mathrm{F}+44(0) 1223315052$

E journals@cambridge.org

or in USA, Canada and Mexico send to:

Cambridge University Press, 32 Avenue of the

Americas, New York NY 10013-2473, USA

T (914) 9379600

F (914) 9374712

E journals_subscriptions@cup.org 